\title{
AIKUISKOULUTUKSEEN OSALLISTUMATTOMUUS ON MYÖS RATIONAALISTA
}

\begin{abstract}
Aikuiskoulutustutkimusten päätuloksista on luettavissa, kuinka suuri osa aikuisista osallistuu vuosittain aikuiskoulutukseen ja kuinka suuri osa ei osallistu. Osallistumisen käytännöt ovat hyvin tiedossa: Työssä olevat osallistuvat työttömiä enemmän, naiset miehiä enemmän ja paljon koulutetut vähän koulutettuja enemmän. Koulutuspoliittisissa teksteissä elinikäinen oppiminen saa positiivisen varauksen, kun iloinen osallistuja on matkalla hyvään elämään ja samalla koko yhteiskunta voi ja menestyy (taloudellisesti) paremmin. Aktiivisista aikuiskoulutukseen osallistujista on olemassa paljon tutkimustietoa, sen sijaan tiedämme vain vähän sellaisista aikuisista, joita koulutus ei kiinnosta.
\end{abstract}

ERJA MOORE

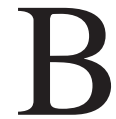
ritanniassa on todettu, että laajoista pyrkimyksistä huolimatta aikuisten koulutukseen osallistumisen eroja ei ole pystytty tasoittamaan eikä aliedustettujen ryhmien koulutukseen osallistumisen astetta nostamaan (McGivney 2001). McGivneyn mukaan menneisyydestä ei ole otettu opiksi, kun laajasta tutkimuksesta ja mittavista aikuiskoulutukseen sijoitetuista investoinneista huolimatta aikuisten osallistuminen heille järjestettyyn koulutukseen on pysynyt ennallaan. Britanniassa tilanne on osittain jopa huonontunut siten, että erot eri yhteiskuntaluokkien ja alueiden välillä ovat lisääntyneet. McGivney kärjistää näkemyksensä toteamalla, että vaikka aliedustettuina olevien ryhmien kanssa työskentelystä on runsaasti tietoa, suuri osa ajasta käytetään sellaisen tiedon ruotimiseen, joka on ollut kaikkien tiedossa jo pitkään. Näin on ylläpidetty "keskiluokan” osallistumista ja jakoa osallistujiin ja osallistumattomiin. (mt. 152-153.)

Ruotsissa toteutettiin vuosina 1997-2002 erityinen aikuisille suunnattu koulutusohjelma, Kunskapslyftet, johon osallistui puoli miljoona aikuista (Friberg 2001). Ohjelman päätavoitteena oli motivoida vähän koulutetut aikuiset osallistumaan koulutukseen, ja se oli tarkoitettu erityis- esti vähän koulutetuille työttömille. Vaikka osallistujamäärät olivat suuret, vaikeinta kohderyhmää eli vähäisen pohjakoulutuksen omaavia keski-ikäisiä pitkäaikaistyöttömiä miehiä ei kyetty tavoittamaan, eikä heidän koulutukseen osallistu-misen malliaan onnistuttu muuttamaan (Paldanius 2002).

Vuonna 2002 Parlamentaarinen aikuiskoulutustyöryhmä esitti mietinnössään

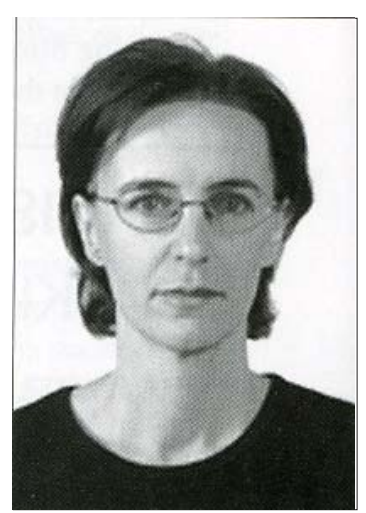

Erja Moore suomalaisen osaamisen nosto-ohjelman käynnistämistä (Opetusministeriö 2002). Vuonna 2003 Suomen hallitus hyväksyi aikuisten koulutustason kohottamista koskevan asetuksen (A41/2003), jonka perusteella käynnistettiin Noste-ohjelma. Ohjelmassa alettiin tarjota vailla toisen asteen tutkintoa oleville 30-54 -vuotiaille, pääasiassa työssä oleville henkilöille mahdollisuus osallistua tutkintoon johtavaan koulutukseen tai suorittaa tutkinnon osia. Vuonna 2004 asetusta muutettiin, ja ikärajaa nostettiin 59 vuoteen (A35/2004). Noste-ohjelman tarkoituksena on parantaa kohderyhmän työelämässä pysymis- 
tä ja urakehitystä, lieventää suurten ikäluokkien eläkkeelle siirtymisestä johtuvaa työvoimapulaa sekä vaikuttaa positiivisesti työllisyysasteeseen (Opetusministeriö 2003). Tällainen ohjelma myötäilee kansainvälisesti hyväksyttyjä tavoitteita, kuten esimerkiksi OECD:n vuonna 1996 asettamaa tunnettua Lifelong Learning for All -tavoitetta universaaleista elinikäisistä oppijoista. Tavoitteella pyrittiin huomioimaan ensinnäkin se, että yksilöiden kompetenssien kehittyminen jatkuu työvoimaan siirtymisen jälkeenkin, ja toisaalta se, että perus-koulutuksen puutteet heijastuvat paitsi työllisyyteen, ansiotasoon ja sosiaaliseen osallistumiseen, myös myöhempään oppimiseen. Vuonna 2001 OECD:n opetusministerit tarkensivat elinikäistä oppimista koskevan tavoitteen Competencies for All -tavoitteeksi, joka kattaa paitsi tarvittavat tiedot ja taidot myös elinikäistä oppimista koskevat asenteet ja arvot (OECD 2001, 2, 4).

Tässä artikkelissa tarkastelen aikuiskoulutukseen osallistumattomuutta sekä valtakunnallisen aikuiskoulutustutkimuksen että elämänhistoriallisten haastattelujen avulla. Esitän ensin määrällisiä tietoja osallistumattomuudesta ja siihen liittyvistä syistä. Noste-ohjelman viitoittamana tarkastelen ikäryhmän 30-59-vuotiaat vastauksia. Lisäksi esitän haastatteluaineiston avulla koulutukseen vähän osallistuvien käsityksiä muodolliseen koulutukseen osallistumisesta.

\section{AINEISTOT}

Artikkelin aineistona on ensinnäkin Aikuiskoulutustutkimus 2000 (AKU2000), joka on neljäs Tilastokeskuksen aikuiskoulutukseen osallistumista kartoittava tutkimus. Tutkimuksen perusjoukkona ovat 18-79-vuotiaat Suomessa vakituisesti asuvat henkilöt. Otoskoko oli 5000, aineisto kerättiin käyntihaastatteluina, ja haastatteluja saatiin 3602. (Blomqvist, Ruuskanen, Niemi \& Nyyssönen 2002, 125, 132.) Tässä artikkelissa käsittelen osallistumattomuuden tematiikkaa tarkastelemalla tutkimukseen osallistuneiden 30-59 -vuotiaiden ( $\mathrm{n}=2326$ ) osallistumista ja osallistumattomuutta aikuiskoulutukseen sekä heidän ajatuksiaan koulutuksesta. 1

Toiseksi käytän aineistona projektissa Osallistumattomuus aikuiskoulutuksen haasteena kerättyjä haastatteluja. Haastatteluihin on pyritty tavoittamaan aikuisia, jotka vakiintuneiden määrittelyjen mukaan ovat aikuiskoulutukseen "osallistumattomia”. Haastatteluja pyrittiin alun perin hankkimaan työvoimatoimiston kautta, mutta nämä yritykset epäonnistuivat, kun vapaaehtoisia haastateltavia ei löytynyt useista yrityksistä huolimatta. Kun käyttöön otettiin ns. lumipallo-otanta, haastateltavaksi on tavoitettu 12 henkilöä, joista miehiä on viisi ja naisia seitsemän. He olivat haastatteluhetkellä 32-59 -vuotiaita. Haastateltavien valinnassa kriteereiksi asetettiin vähäinen osallistuminen tai osallistumattomuus aikuiskoulutukseen ja aikuisuus, jota tässä määritettiin väljästi kronologisen iän avulla (ks. Koski \& Moore 2001). Haastatelluista yhdeksän täyttäisi Noste-ohjelman kriteerit paitsi ikänsä myös peruskoulutuksensa osalta. Kolmella haastatellulla on ammatillinen tutkinto. Neljä haastateltavaa tavoitettiin työvoimatoimiston järjestämältä pitkäaikaistyöttömille tarkoitetulta kurssilta. ${ }^{2}$

Haastatteluaineisto on kerätty elämänhistoriallisen lähestymistavan mukaisesti (ks. Moore 2003). Haastateltavia pyydettiin kertomaan vapaamuotoisesti koulutus- ja työhistoriansa, ja näin haastattelut sisältävät koulutukseen ja työhön liittyviä kokemuksia ja käsityksiä. Laadullisen aineiston avulla on mahdollista tarkastella ja analysoida koulutukselle annettuja merkityksiä laajemmassa elämänkulun viitekehyksessä. Haastateltujen aikuisten kertomukset, joissa keskiössä ovat osallistuminen muodolliseen koulutukseen ja työelämään elämän kuluessa, peilaavat jaettuja kulttuurisia oletuksia ja ideoita koulutuksesta. Haastateltavien kertomuksia elämästään ei nähdä pelkästään yksittäisinä elämäntarinoina, vaan niiden ajatellaan heijastavan ja olevan "osa laajemman yhteiskunnan valtasuhteita ja kilpailevia totuuksia” (Bron \& West 2000, 160).

Artikkelissa tarkastellaan aikuisten osallistumista ja osallistumattomuutta koulutukseen elämänkulun näkökulmasta sekä kvantitatiivisen että kvalitatiivisen aineiston avulla. AKU2000aineiston vastaajat ovat haastattelutilanteessa kertoneet koulutukseen osallistumisestaan valitsemalla omaa ajatteluaan ja toimintaansa kuvaavan vaihtoehdon annettujen valmiiden vaihtoehtojen joukosta. Näiden vastausten perusteella voidaan esittää yhdenlainen tulkinta siitä, miten aikuiset osallistuvat aikuiskoulutukseen elämänsä kuluessa. Haastatteluaineiston avulla on mahdollista esittää, millainen käsitys aikuiskoulutukseen vähän tai ei koskaan osallistuvilla haastateltavilla on koulutuksesta ja siihen osallistumisesta omassa elämäntilanteessaan. 
OSALLISTUMISEN JA

OSALLISTUMATTOMUUDEN KÄYTÄNNÖT

Aikuiskoulutusta käsittelevissä tutkimuksissa toistuvat tietyt tulokset sekä kansallisesti (esim. Blomqvist et al. 2002) että kansainvälisesti (esim. Belanger \& Valdivielso 1997). Esimerkiksi Gorard ja Rees $(2002,101)$ viittaavat lukuisiin Britanniassa tehtyihin tutkimuksiin, joissa on tunnistettu vähiten aikuiskoulutukseen osallistuvia ryhmiä. Työttömät, muut alhaisen tulotason omaavat, ammattitaidottomat ja ammattikouluttamattomat, (ex-)rikolliset, osa-aikaista tai määräaikaista työtä tekevät, oppimisvaikeuksia omaavat, alhaiset perustaidot omaavat ja jotkut tietyt etniset ryhmät osallistuvat aikuiskoulutukseen vähän tai ei lainkaan (ks. myös McGivney 2001, 21-22). Suomalaisten aikuiskoulutustutkimusten tulokset ovat samansuuntaisia, vaikkei meillä olekaan tapana nimetä osallistumattomien ryhmiä yhtä kategorisesti kuin edellä mainitussa tutkimuksessa. Suomessa lähes puolet aikuisväestöstä (18-64 vuotiaista) ei ole osallistunut aikuiskoulutukseen edellisen 12 kuukauden aikana (esim. Blomqvist et al. 2002). Tällainen poikkileikkausluku vaikuttaa melko suurelta, mutta jos osallistumista tarkastellaan elämänkulun näkökulmasta, vain kuudella prosentilla aikuisväestöstä ei ole kokemuksia aikuiskoulutuksesta (Moore 2002).

Taulukossa 1 esitetään 30-59 -vuotiaiden, työvoimaan kuuluvien aikuisten osallistuminen ja osallistumattomuus aikuiskoulutukseen koulutustason mukaan. Vastaajien koulutustaso on jaettu kolmeen eri luokkaan tutkintorekisterissä olevien tietojen mukaan. ${ }^{3}$ Taulukon perusasteen tutkinnon suorittaneet vastaavat Noste-ohjelman kohderyhmää.

Kun osallistumista tarkastellaan elämänkulun näkökulmasta, on huomattavaa, että vain kolme prosenttia 30-59-vuotiaasta työvoimasta ei ole koskaan osallistunut aikuiskoulutukseen. Osallistumattomia on eniten niiden joukossa, joilla on vähiten peruskoulutusta. Aikuiskoulutukseen aktiivisesti osallistuvilla on selkeästi korkeampi koulutustaso kuin niillä, jotka eivät osallistu tai jotka osallistuvat vain vähän. Neljä viidesosaa tämän ikäryhmän korkea-asteen koulutetuista on osallistunut aikuiskoulutukseen edellisen vuoden aikana.

Suurin osa aikuiskoulutuksesta toteutuu oppilaitosten ulkopuolella, työssä tapahtuvana tai työnantajan järjestämänä koulutuksena. Osallistuminen riippuu merkittävästi myös (koulutustason kanssa korreloivasta) sosioekonomisesta asemasta. Kun 84 prosenttia ylemmistä toimihenkilöistä osallistuu vuosittain aikuiskoulututukseen, vastaava luku työntekijäasemassa olevien osalta on 45 prosenttia (Blomqvist 2002 et al.; Moore 2002). Aikuiskoulutukseen osallistumista ja osallistumattomuutta voidaan tarkentaa taulukon 2 avulla. Siihen on koottu haastateltavien ilmoittama työhön ja ammattiin liittyvään aikuiskoulutukseen osallistumiskertojen määrä.

Kymmenen prosenttia 30-59 -vuotiaasta työvoimasta ilmoittaa, ettei ole koskaan osallistunut työhön tai ammattiin liittyvään aikuiskoulutukseen. Osallistumisen erot eri koulutustasoja edustavien välillä ovat suuret. Perusasteen suorittaneista lähes viidennes ei oman ilmoituksensa mukaan ole koskaan osallistunut työhön tai ammattiin liittyvään aikuiskoulutukseen. Kun 70 prosenttia korkea-asteen tutkinnon suorittaneista ilmoittaa osallistuneensa työhön tai ammattiin liittyvään aikuiskoulutukseen yli 10 kertaa työelämään siirtymisen jälkeen, vastaava osuus perusasteen suorittaneista on kolmannes.

Kansainvälisissä vertailuissa suomalaisten aikuisten koulutukseen osallistumattomuus näyttää kuitenkin vähäiseltä. Gorardin ja Reesin (2002)

\begin{tabular}{|lllll|} 
& $\begin{array}{l}\text { Edellisen 12 kk } \\
\text { aikana }\end{array}$ & $\begin{array}{l}\text { Joskus } \\
\text { aiemmin }\end{array}$ & Ei koskaan & Yhteensä \\
Perusaste & 44,3 & 49,6 & 6,1 & $100(\mathrm{~N}=500209)$ \\
Keskiaste & 54,6 & 43,2 & 2,2 & $100(\mathrm{~N}=795979)$ \\
Korkea-aste & 79,8 & 19,2 & 1,0 & $100(\mathrm{~N}=645263)$ \\
Yhteensä & 60,3 & 36,9 & 2,8 & $100(\mathrm{~N}=1941451)$ \\
\hline
\end{tabular}

Taulukko 1. Työvoimaan kuuluvien 30-59-vuotiaiden osallistuminen aikuiskoulutukseen koulutustason mukaan prosentteina ( $n=2039, N=1941451$ ). $n=$ haastateltujen lukumäärä, $N=$ aineistoon sisällytetyn painokertoimen avulla tehty korotus väestötasolle. Taulukoissa on käytetty korotuspainoa. 


\begin{tabular}{|llllll|}
\hline & ei & 1-3 kertaa & 4-10 kertaa & yli 10 kertaa & Yhteensä \\
& kertaakaan & & & & \\
Perusaste & 18,6 & 20,1 & 28,6 & 32,7 & $100(\mathrm{~N}=488491)$ \\
Keskiaste & 10,3 & 23,4 & 24,4 & 41,0 & $100(\mathrm{~N}=788640)$ \\
Korkea-aste & 2,8 & 9,0 & 18,8 & 69,4 & $100(\mathrm{~N}=640319)$ \\
& & & & & \\
Yhteensä & 9,5 & 17,6 & 24,0 & 48,3 & $100(\mathrm{~N}=1917450)$ \\
& & & & & \\
\hline
\end{tabular}

Taulukko 2. Työvoimaan kuuluvien 30-59-vuotiaiden arviot osallistumisestaan työhön tai ammattiin liittyvään aikuiskoulutukseen työelämään siirtymisen jälkeen $4 \%,(n=2015, N=1917450)$.

toteuttamassa aikuisten oppimaan osallistumista kartoittaneessa tutkimuksessa $(n=1104)$ Walesissä 31 prosenttia vastanneista voitiin luokitella ei-osallistujiksi. He ilmoittivat, etteivät olleet jatkaneet koulutustaan millään tavoin oppivelvollisuuskoulun päättymisen jälkeen, eivät olleet osallistuneet aikuis- tai täydennyskoulutukseen, eivät työvoimapoliittiseen koulutukseen eikä heillä ollut kokemusta merkittävästä työssä oppimisesta (work-based training) (Gorard \& Rees 2002, 44). Samalla tavoin myös McGivney (2001, 13-15) raportoi aikuisten oppimista koskevasta tutkimuksesta vuodelta 2001 ( $\mathrm{n=6310)}$ ), jossa 33 prosenttia vastaajista ilmoitti, ettei ollut osallistunut koulutukseen (tai oppimiseen) sen jälkeen, kun oli lopettanut kokopäiväisen koulunkäynnin nuoruudessaan.

\section{NÄKÖKULMIA OSALLISTUMATTOMUUTEEN}

AKU2000-tutkimuksessa kartoitettiin, mitkä seikat estävät koulutukseen osallistumista. Suurimmaksi työhön liittyvien opintojen esteeksi valittiin valmiiden kysymysvaihtoehtojen joukosta kiireet työpaikalla. Suurin este kuitenkin vaihtelee sen mukaan, miten on aiemmin osallistunut. Työhön liittyvään koulutukseen edellisen vuoden aikana osallistuneet nimesivät suurimmaksi osallistumisen esteeksi kiireet työpaikalla, mutta ne, jotka olivat osallistuneet koulutukseen joskus aiemmin tai jotka eivät olleet koskaan osallistuneet, mainitsivat suurimmaksi esteeksi, että työnantaja ei järjestä koulutusta. Vapaa-ajan opintojen suurimmaksi esteeksi työssä olijat valitsivat hankalat tai epäsäännölliset työajat, työttömät taas pitivät suurimpana esteenä koulutukseen osallistumiselle taloudellisia tekijöitä. Sen sijaan vähäinen pohjakoulutus tai epä- onnistumisen pelko eivät muodosta merkittävää estettä opiskelulle.

Vaikka aikuiskoulutustutkimuksissa on kehitetty erilaisia osallistumista ennakoivia mittareita ja malleja, on kuitenkin huomattu, etteivät tällaiset instrumentit kykene tarkasti osoittamaan aikuiskoulutukseen osallistumattomuuden syitä tai osallistumisen esteitä (Cutz ja Chandler 2000).

Cutz ja Chandler (2000) hakevat artikkelissaan selvitystä monien aikuiskoulutusohjelmien epäonnistumiselle. He tulkitsevat tilannetta niin, että koulutuksen järjestäjien ja siihen tarkoitettujen osallistujien välillä on olemassa ns. emic - etic ristiriita, mikä voisi olla ratkaiseva selittäjä sille, että aikuiskoulutuksessa on usein epäonnistuttu tavoittamaan kohderyhmiä, joilla on takanaan vähän muodollista koulutusta. Etic käsittää yleisiä ajattelumalleja kuten väittämiä, määritelmiä ja luokitteluja. Tällaiset lausumat ovat perustana silloin, kun ilmiöitä tai ihmisiä luokitellaan ryhmiin tai määritellään jonkun ryhmän piirteitä. Aikuiskoulutuksessa etic on perustietoa tai tutkimustietoa, jonka avulla ilmiötä (kuten aikuiskoulutukseen osallistumisen käytäntöjä) tutkitaan ja tulkitaan.

Emic taas on validia vain melko yhtenäiselle ryhmälle tai kielelle. Se sisältää kulttuurisen toiminnan malleja, jotka määrittävät ja ohjaavat tietyn ryhmän ihmisten käyttäytymistä, tietoja ja asenteita. Emic ei ole tutkijoiden tai asiantuntijoiden luomaa, vaan jossain kulttuurissa olevaa, osittain perittyä ja uusiutuvaa toiminnan tapaa, joka ilmenee esimerkiksi eri ryhmien erilaisena suhtautumisena formaaliin koulutukseen. Kun tähän tutkimukseen tavoitetut haastateltavat kertoivat vapaamuotoisesti ajatuksiaan koulutuksesta ja työstä, on mahdollista tavoittaa aikuiskoulutukseen osallistumattomien emic-tietämystä näistä teemoista. 


\section{MINÄ KOULUNPENKILLÄ}

Haastateltavat muistavat ensimmäiset kouluvuodet miellyttävinä ilman erityisiä ongelmia, ja koulunkäynti kuvataan enimmäkseen mukavana. Näyttää kuitenkin siltä, että eri sukupuolta olevat kertovat koulukokemuksistaan jossain määrin eri tavoin. Naisten kertomuksia koulunkäynnistään ei sävytä negatiivisuus, vaikka joitakin pelottavia tilanteita tai opettajia muistettiin haastatteluissa. Lähes kaikki haastatellut naiset kertovat itsestään siten, että he olivat koulussa hiljaisia ja ujoja. Myös ahkeruus ja läksyjen lukeminen ovat jääneet mieleen koulumuistoissa:

Olen ollut vähän semmonen hiljainen, miten sen sanois (naurua). Aika hankala kuvailla itseään, hiljainen, semmonen rauhallinen, et tehnyt aina työni siellä. Kyllä minä sillä lailla, täytyis kysyä joltakin muulta, opettajalta. (naurua) (nainen 41 v., pätkätöitä)

Alakoulussa oli sellanen, että oikein paniikki oli aina, että piti uskonnon läksy osata. Se tuli karttakepin kanssa, se oli miesopettaja joka piti sitä uskontoa. Jos ei osannut, se tuli tapittamaan silmästä silmään ja karttakepillä hakkaamaan tähän pulpettiin. Ei se ikään mulle tullut, mutta sitä aina pelkäsi. Minähän pelkäsin ja luin. (nainen 45v., töissä)

Miesten kertomuksissa negatiiviset koulukokemukset ovat voimakkaampia. Ne alkavat lähinnä viimeisten pakollisten kouluvuosien aikana, jolloin koulu aletaan kokea epämukavana paikkana. Miesten kertomuksissa on mainintoja levottomuudesta luokkahuoneessa, ongelmista oppimisessa tai ongelmista ja riidoista opettajien kanssa. Seuraavassa aineistolainauksessa haastateltava kertoo, miten yksi ainoa kouluaine aiheutti hänelle vaikeuksia koulussa:

Haastattelija: (...) matematiikan mainihit ?

Haastateltava: Noo se hirvittää vieläkin. [...]

Enkä oo tähänkään päivään mennessä mitään hypotenuusaa tai muutakaan tarvinnut, ihan sujuvasti on mennyt. En tiedä minkä takia ne paukuttaa noita. Tietysti joillekin siitä on hyötyä ja joillekin ei. Minä oon ainakin ollut ihan tyytyväinen ilman noita tommosia.

(mies, 37v, työtön)

Seuraavassa aineistolainauksessa koulunkäynnistään kertova haastateltava kävi peruskoulun kahdeksannen luokan kaksi kertaa ja siirtyneen- sä yhdeksännen luokan jälkeen heikon todistuksen saaneena ammatilliseen koulutukseen, jonka keskeytti 18-vuotiaana yhden lukuvuoden jälkeen. Opiskelu ja osallistuminen muodolliseen koulutukseen oli jotain sellaista, mikä ei häntä kiinnostanut.

Niin, olin sen kevään, se kiinnostus lopahti oikeestaan ihan kokonaan, tämmösiin fysiikkaan, kemiaan, matikkaan ja no, englantiin. Ruotsia siellä ei opiskeltu yhtään. Englanti ei kiinnostanut enää yhtään. Minä olin jo niin täynnä sitä koko englantia ja samoin matikka oli ihan jollain tavalla käsittämättömän älyttömiä kaavoja, joista minä en oppinu ymmärtämään koko aikana mitään, mutta jotenkin minä vain ja samaten fysiikka ja kemia, älyttömiä kaavoja ja laskentoja, joista minä en tajunnut tuon taivaallista. (mies, 33v., töissä)

Haastateltavien kertomuksissa toistuvat ilmaisut "koulunpenkki” ja "koulunpenkillä istuminen", mihin liitetään ajatus koulusta itselle vaikeana, vieraana ja sopimattomana. Koulusta kerrotaan paikkana, jonne itse ei välttämättä kokenut kuuluvansa. Myös mahdollinen aiempi osallistuminen aikuiskoulutukseen on voitu kokea koulumaisena.

Mutta kyllähän koulunkäynti on tosi vaikeaa, kun niinku mäkin oon lähtenyt heti työelämään [...] silloin kun menin autonkuljettajan kurssille, niin siellähän on muutakin kuin ajoa, siellä istutaan 8-16 tunnilla, niin siellä pökkäs sellaiset aineet jotka ei niin kiinnostanut. (nainen, 51v., töissä)

Äärimmillään koulusta on jäänyt kuva ”tappelupaikkana”, ja yhden haastatellun miehen kertomusta koko koulunkäyntinsä ajalta sävyttävät kertomukset erilaisista tappelutilanteista.

Haastateltava: Rehtori, sehän oli piru hakkaamaan.

Haastattelija: Joo, no, mitä piti tehdä, että tuli?

Haastateltava: No, ei tarvinnu kyllä kovin pahastikaan, jotakin resus tunnillakin, niin kyllä niskasta vietiin nurkkaan, niin jos siinä liikku, niin kyllä tuli nyrkkiä. Ja monesti oltiin naulakossa vielä kiinni. (naurua) (mies, 47 v., pätkätöissä)

Vaikka joihinkin kouluaineisiin liitetään negatiivisia kokemuksia ja oppimisvaikeuksiakin, haasta- 
teltavat kertoivat merkittävistä oppimiskokemuksista etenkin työssä mutta myös muissa tilanteissa, joissa muodollinenkin opiskelu oli mielekästä. Edellä ammattikoulun keskeyttämisestä kertonut mies kuvaa autokoulun käymistä seuraavasti:

Niin minä sitten tein sen kirjallisen. Minä olin ilmiselvästi kaikista nopein ja täytin sen lapun ja katsastusmieskin katsoi ihmeissään kun minulla meni kahdeksan minuuttia. (...) Ja sitten, [opettaja sanoi] näytäs nyt montako virhettä, vähän aikaa katto, ei yhtään, hän ei oo nähny eläissään vielä, että joku noin nopeasti tuon paperin tekis, käy heittämässä ja lähtee pois. Minä siihen että kyllä sitä on luettukin, sitä sitä oli luettu. (mies, 33v., töissä)

\section{TYÖN JA PERHEEN ENSISIJAISUUS}

A ikuisille suunnitellut koulutukset perustuvat ajatteluun yksilön opintourasta, jossa koulutus on tavallaan erotettu omaksi sarakseen ihmisen elämänkokonaisuudessa. Aikuisen elämänkoko-naisuuteen kuitenkin kuuluvat usein myös perhe ja lähiyhteisö, eikä yksilö välttämättä tee tai voi tehdä koulutukseen osallistumispäätöstä pelkästään omien tarpeidensa pohjalta. Tähän tutkimukseen haastatelluista etenkin naiset kertoivat elämästään siten, että perhekokonaisuus tutun elinympäristön kanssa olivat ja ovat elämän keskiössä, olivatpa he työssä tai työttöminä. Perheeseen liittyvien tunne- ja vastuutekijöiden lisäksi taloudelliset tekijät mainitaan erikseen yhtenä esteenä ainakin ammatilliseen koulutukseen osallistumiselle. Koulutukseen osallistumattomuuden perusteluna mainitaan myös ikä.

Haastattelija: Oliko vaihtoehtona, että olisit lähtenyt jonnekin kauemmaksi kouluun?

Haastateltava: Kyllä mä tätä läheltä kattelin. Ei sitä silloin ollut valmis lähtemään kauemmaksi, sen verran "mettäpöhlö" vielä olin sillon. (nainen, 43v., töissä)

Haastattelija: Entäs sitten ihan tavallinen ammatillinen koulutus?

Haastateltava: Millä rahalla nykyään? Kuka maksaa laskut, jos lähet tonne koulutukseen ynnä muuta. (mies, 50v., työtön)

Tykkään tehdä tämmösiä pätkätöitä, jotta saa olla, varsinkin nyt kun lapset on nyt, kun lapset on olleet pienenä, niin se on kauhean tärkeää oli olla kotonakin. [...] Siitä on jo aikaa, kun nämä oli pieniä, niin meinasin lähteä lähihoitajakoulutukseen, ja nythän se alko taas, mutta tutkin että en minä siihen enää lähdekkään. (naurua) [...] Se vaan tuntu sillai, että en enää nyt, että en ole enää siinä. Sekin on se opiskelu lähihoitajaksi niin ikä, minä kuitenkin kun 41 olen, niin ei sitä välttämättä enää jaksa tehdä. Se on aika raskasta [...] ja onhan se tietenkin täälläkin rahakysymys, että lähet kouluun, että jos sulla töitä on kerran, niin siinä täytyy vähän valita, että kumman otat, minä otin nyt työt. (nainen, 41 v., pätkätöissä)

Kun haastateltavat kertovat työstään ja eri työpaikoistaan, he kertovat myös oppimisesta, joka tapahtuu työssä, kun työpaikoilla pitempään olleet työntekijät opettavat uudelle työntekijälle tarvittavat taidot. Myös AKU2000-aineistosta on todettavissa, että etenkin vailla toisen asteen tutkintoa olevat aikuiset ovat oman arvionsa mukaan hankkineet tietoja ja taitoja merkittävästi enemmän työssä kuin peruskoulutuksessaan (Moore et al. 2003; Moore \& Antikainen 2003).

Haastateltava: Siinä mielessä että koulunpenkille lähtisin niin ei enää. Jos suoraan töihin pääsis niin sinne. Se on ihan väärää luuloa, että siellä koulussa sitä oppis. Ei sitä välivaihetta enää, että ensin kouluun ja sieltä töihin. Suoraan kun pääsee siihen paikan päälle, niin siinä. (mies, 48v., työtön)

Että jos vaikka oppisopimukseen pääsis tai muuta sinne töihin. Sitä kautta olis paljon nopeempi päästä töihin, kuin jos lähtis jonnekin kouluun ja opiskelemaan.(nainen, 32v., työtön)

Haastateltava: No en mä kyllä rupeais oikein koulunpenkillä käymään enää, kun on tuota ikää. Mutta eihän nämä tällaiset kurssit, jotka työhön liittyy, nämä palaverit mitä on, niin ihan ok.

Haastattelija: Eikös täälläkin (=työpaikalla) nyt ole joku kurssi tai koulutus?

Haastateltava: Niin olis, mut en mä. Nythän sais hakea sinne uuteen koulutukseen (=Nostekoulutus), mutta en minä sinne, ei musta sellaseen ole enää, en pystyisi enää.

(nainen, 45v., töissä)

Haastateltavat antavat työlle ja työn hankkimiselle korkean arvon paljolti samaan tapaan kuin Paldaniuksen (2002) tutkimukseen osallistuneet 
työttömät Ruotsissa. Työ on ensisijaista suhteessa koulutukseen, eikä muodollinen koulutus, kuten esimerkiksi ammattitutkinnon hankkiminen näyttäydy omaan elämäntilanteeseen sopivalta tai itselle mahdolliselta.

\section{OSALLISTUMATTOMUUDEN RATIONAALISUUS}

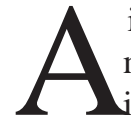

ikuisten koulutukseen osallistumattomuus on mielenkiintoinen kulttuurinen ilmiö, joka vaikuttaa saavan samanlaisia piirteitä useissa jälkiteollisissa maissa. Paldanius (2002), joka tutki väitöskirjassaan ongelmia työttömien rekrytoimisessa koulutukseen Ruotsissa, päätyy toteamaan, että työttömille voi olla rationaalista olla osallistumatta aikuiskoulutukseen, koska he eivät koe koulutuksen olevan keino tai väline oman tilanteensa paranemiseen. Myös tähän tutkimukseen haastatellut henkilöt, jotka ovat osallistuneet koulutukseen vähän, useimmat kansakoulun tai peruskoulun ajan, pitävät ensisijaisena tavoitteenaan työtä, joko työn hankkimista tai työssä pysymistä.

Monien tutkimusten perusteella on selvää, että kaikki eivät jaa koulutus- tai oppimisyhteiskunnan ideaalia aktiivisesta jatkuvasti oppia hakevasta aikuiselämästä. Tämä ilmenee jo niistä tuloksista, jotka kertovat työn ja koulutuksen ulkopuolelle jäämisestä. Vaikka suurin osa nuorista toteuttaa koulutuksen kulttuurista käsikirjoitusta, eli hakeutuu peruskoulun jälkeen joko ammatillisiin tai lukio-opintoihin, osa kustakin ikäluokasta syrjäytyy jo ennen aikuisuutta sekä koulutuksesta että työstä. ${ }^{5}$ Tähän saakka haastattelemistamme henkilöistä kukaan ei kuitenkaan ole avoimesti kyseenalaistanut tai vastustanut koulutuksen tai elinikäisen oppimisen merkitystä yleisellä tasolla. Sen sijaan haastateltavat ovat kertoneet elämästä, jossa koulutuksella ei ole merkittävää roolia. He kertovat elämästä ja elämäntavasta, jossa yhteiskunnasta on löytynyt paikka ja osa ilman sitoutumista jatkuvan koulutuksen ja elinikäisen oppimisen eetokseen. Tällaiset koulutusta koskevat erilaiset kulttuuriset toiminta- ja ajattelumallit voivat olla taustalla esimerkiksi silloin, kun eri sosioekonomisiin ryhmiin kuuluvat henkilöt osallistuvat koulutukseen eri tavoin tai kun vähän koulutetut eivät osallistu heille suunnattuun koulutukseen.

Koulutukseen vähän osallistuvien näkemysten tavoittaminen tutkimuskäyttöön on vaikeaa, ja ilmiönä osallistumattomuus näyttää "pakenevan” tutkimusta. Tästä on esimerkkinä oma tutkimuksemme, johon ei saatu työvoimatoimiston kautta vapaaehtoisia haastateltavia. Myös AKU2000 -tutkimuksen vastauskato painottuu vailla toisen asteen tutkintoa oleviin, joiden tiedetään osallistuvan vähiten aikuiskoulutukseen. Otoksen korkeakoulutetuista 18 prosenttia kieltäytyi haastattelusta, mutta perusasteen suorittaneista kieltäytyjiä oli 26 prosenttia (Blomqvist et al. 2002, 130).

Vähemmän koulutetuille aikuisille tarjottavien erityisten koulutusmahdollisuuksien heikkoutena voi olla kohderyhmäksi ajatellun ryhmän emicnäkemysten puuttuminen suunnittelusta. Tällöin vaarana on, että suunnitelmat vastaavat korkeimmin koulutettujen tarpeisiin, joiden emic-näkemykset lähenevät tutkijoiden ja suunnittelijoiden näkemyksiä. Tällaisen kulttuurisen käsityksen avulla on ymmärrettävää, miksi korkeasti koulutetut osallistuvat koulutukseen enemmän, ja miksi heillä on enemmän aikeita osallistua koulutukseen. Osa aikuisväestöstä ei hakeudu ilman erityistoimia koulutukseen, mikä asettaa mittavan haasteen aikuiskoulutukselle.

\section{LÄHTEET}

\section{A41/2003. Valtioneuvoston asetus aikuisten} koulutustason kohottamiseen myönnettävästä valtionavustuksesta.

A35/2004. Valtioneuvoston asetus aikuisten koulutustason kohottamiseen myönnettävästä valtionavustuksesta. 22.1.2004.

Belanger, P. \& Valdivieso, S. (eds.) (1997). The Emergence of Learning Societies: Who participates in Adult Learning? Great Britain: Galliard Printers LTD.

Blomqvist, I., Ruuskanen, T., Niemi, H. \& Nyyssönen, E. 2002. Osallistuminen aikuiskoulutukseen. Aikuiskoulutustutkimus 2000.Tilastokeskus.

Bron, A \& West, L.(2000). Time for stories: the emergence of life history methods in the social sciences. International Journal of Contemporary Sociology 37 (2): 158-174.

Cutz, G. \& Chandler, P. (2000). Emic-etic conflicts as explanation of non-participation in adult education among the Maya of Western Guatemala. Adult Education Quarterly 51(1): 64-76.

Friberg, N. (2001). ”Kunskapslyftet” A Nation 
Mobilised for Adult Learning. Lifelong Learning in Europe VI, 1.

Gorard, S. \& Rees, G. (2002). Creating a Learning Society? Learning careers and policies for lifelong learning. Bristol: Policy Press.

Kokkila, H. (2003). Elinikäiseksi oppijaksi aikuisiällä? Vailla toisen asteen tutkintoa olevien 30-54-vuotiaiden osallistuminen aikuiskoulutukseen ja käsitykset koulutustarpeesta. Sosiologian pro gradu-tutkielma. Joensuun yliopisto.

Koski, L. \& Moore, E. (2001). Näkökulmia aikuisuuteen ja aikuiskasvatukseen. Aikuiskasvatus 21(1), 4-13.

McGivney, V. (2001). Fixing or changing the pattern? Reflections on widening adult participation in learning. Leicester: NIACE.

Moore, E. (2002). Osallistuu - ei osallistu. Osallistumattomuus aikuiskoulutuksen haasteena. Ammatinvalinnanohjauksen vuosikirja 2002. Työministeriö, 19-29.

Moore, E. (2003). Pitkä opintie. Aikuisiällä suoritettu yliopistotutkinto ja koulutuksellisen elämänkulun muutos. Joensuun yliopistopaino.

Moore, E., Tikka, T. \& Antikainen, A. (2003). The Importance of Work and Education in an Informational Society. In Bron, A. \& Schemmann, M. (eds) Knowledge Society, Information society and Adult Education. Bochum Studies in International Adult Education, vol. IV. Munster, Hamburg, London: LIT.

Moore, E. \& Antikainen, A. (2003). Can a state intervention challenge the pattern of participation in adult education? In D. Wildemeersch \& V. Stroobants (ed.) Connections: Proceedings of the 'Connections' Conference Organized by the Active Citizenship Network of ESREA and the Solgace Research Consortium. Centre for Comparative, Intercultural and Development Pedagogy, Katholieke Universiteit Leuven, 189-204.

OECD 2001. Investing in Competencies for All. Meeting of OECD Education Ministers. Issues for Discussion. http://www.oecd.org/ els/pdfs/EDSMINDOCA002.pdf.

Opetushallitus 2003. OECD:n Education at Glance 2003. Suomenkielinen tiivistelmä. http://www.oph.fi/age.asp?path=1,439,3131,$12637,24261,24269$
Opetusministeriö 2002. Parlamentaarisen aikuiskoulutustyöryhmän mietintö.

Opetusministeriö 2003. Noste-ohjelma 2003-07. Aikuisten koulutustason kohottamis-ohjelman toimeenpano ja rahoitus opetusministeriön hallinnonalalla. Luonnos 14.2.2003.

Paldanius, S. (2002). Ointressets rationalitet. Om svårigheter att rekrytera arbetslösä till vuxenstudier. Linköping Studies in Education and Psychology No. 86. Linköping.

\section{VIITTEET}

1. AKU2000 -tutkimuksessa osallistuminen aikuiskoulutukseen kattaa hyvin erilaisia koulutustilanteita. Aikuiskoulutukseen osallistujaksi määrittyvät niin henkilöt, jotka osallistuvat yhteen vähintään kuusi tuntia kestävään aikuisille järjestettyyn koulutukseen kuin henkilöt, jotka hankkivat ammatillista tutkintoa aikuiskoulutuksen piirissä tai osallistuvat omaehtoiseen, harrastuksenomaiseen koulutukseen. Tätä jaottelua seuraten osallistujia eivät kuitenkaan ole ne aikuiset, jotka opiskelevat (lähinnä nuorille tarkoitetussa) koulujärjestelmäkoulutuksessa. Esimerkiksi aikuisten tutkintoon johtava opiskelu yliopistoissa rajautuu aikuiskoulutuksen ulkopuolelle (ks. Moore 2003, 37-42).

2. Kurssille osallistujat ovat virallisesti aikuiskoulutuksen piirissä. Tällaisista kursseista kuitenkin puhutaan nimityksellä "pakkokoulutus”, johon ohjaudutaan työvoimaviranomaisten välityksellä esimerkiksi ansiosidonnaisen päivärahakauden päättyessä.

3. Kokkila (2003, 35-36) on Noste-tutkimuksessaan osoittanut, että yksilöt määrittelevät ja mieltävät itse oman koulutustasonsa eri tavoin kuin tutkintorekisterissä käytetty luokitus.

4. Haastateltavilta kysyttiin: ”Kuinka monta kertaa olette arviolta ollut yhteensä työhön tai ammattiin liittyvillä kursseilla tai koulutuksessa sen jälkeen, kun siirryitte työelämään?” Taulukosta 2 on poistettu peräti 17 vastaajaa, jotka vastasivat kysymykseen valitsemalla vaihtoehdon "ei osaa sanoa”.

5. Etenkin suomalaispojat ovat vaarassa syrjäytyä, sillä 15-19-vuotiaista pojista 12 \% ei ole sen enempää koulutuksessa kuin työssäkään. Tyttöjen vastaava osuus on 3,7 \%. (Opetushallitus 2003.)

Artikkeli saapui toimitukseen 22.3.2004. Se hyväksyttiin julkaistavaksi 18.8.2004. 